肝虚血再灌流障害発生における細胞内 superoxide 産生系の関与 - CuZn-SOD 過剰発現トランスジェニックマウスを用いた検討一

$\begin{array}{llllll}\text { 竹内 } & \text { 丙午 } & \text { 鈴木 } & \text { 正徳 } & \text { 福原 } & \text { 賢治 } \\ \text { 海野 } & \text { 倫明 } & \text { 八巻 } & \text { 孝之 } & \text { 松野 } & \text { 正紀 }\end{array}$

要 旨：肝の虚血再灌流障害における, 細胞質 superoxide dismutase (SOD) の意義を検討する ため, 細胞質分画の SOD 活性が通常マウスの1.8倍に上昇した transgenic mouse を用いて検討 を行った。 15分間の $70 \%$ 部分肝虚血，45分間の再灌流を行い, 血獎 ALT, ヒアルロン酸濃度, 肝組織中の膜脂質過酸化物 phosphatidylcholine hydroperoxide (PCOOH) を測定した.ALT お よび PCOOH は通常マウスで再灌流による増加を認めたが, transgenic mouse では増加が抑制 された. 両群でヒアルロン酸值は上昇を認めなかった. 肝虚血再灌流障害の発生には細胞内で 産生される superoxide が関与しており, 細胞内活性酸素消去能の向上は再灌流障害の予防に寄 与するものと考えられた。

索引用語： 肝虚血再灌流障害 活性酸素 superoxide dismutase 脂質過酸化

はじめに

肝臓は血管の豊富な実質臓器であるため, その切離 に際して流入血行の血流遮断が行われ，血流再開後の 再酸素化により組織が傷害される，いわゆる虚血再灌 流障害が生じる. 再灌流障害の発生機序に関しては, 種々の生体内産生系により生成される活性酸素が主要 な障害因子であると考えられてきた ${ }^{1,2)}$. 活性酸素は, 生体膜の主要構成成分である phosphatidylcholine を 過酸化し, 種々の細胞機能障害を生じていると考えら れている.われわれはこの phosphatidylcholine の過酸 化物である phosphatidylcholine hydroperoxide (PCOOH)の特異的定量法を用い, $\mathrm{PCOOH}$ が活性酸素 による肝細胞障害の鋭敏な指標となることを報告して きた ${ }^{3,4)}$.

当初 Granger ら ${ }^{5)}$ により提唱され, 活性酸素の主な産 生源と考えられてきたキサンチンオキシダーゼ系など により細胞内で産生される superoxide $\left(\mathrm{O}_{2}^{-}\right)$が, 再灌流 障害の発症に重要な役割を果たすと考えられてきた。 一方, 近年活性酸素の産生系として, 好中球など貪食 細胞の細胞膜上に局在する NADPH oxidase 系が明ら かとなり, 再灌流障害の原因として重視されている.

東北大学第 1 外科

<受付日1998年 5 月29日 $>$
すなわち貪食細胞が産生し細胞外に向けて放出される $\mathrm{O}_{2}^{-}$が, 類洞内皮細胞や肝実質細胞の細胞膜を傷害する ことにより組織障害, 肝細胞機能障害が生じると考え られている ${ }^{6 \sim 10)}$. しかし細胞内で産生される $\mathrm{O}_{2}^{-}$が虚血 再灌流障害に寄与しているか否かは, 現在もなお議論 のあるところである。

$\mathrm{O}_{2}^{-}$の唯一の分解酵素である superoxide dismutase (SOD) の外因性投与では, SOD 自体が細胞膜を通過し ない.このため, 人為的に細胞質の SOD 活性を修飾す ることはほとんど不可能であった. 1987年, Epstein ら ${ }^{11)}$ は細胞質で CuZn-SODを過剩発現する transgenic mouse の作成を報告した. 本研究ではこの SOD 過唾発 現マウスを用いて，腸管鬱血によるエンドトキシン血 症の影響を除外するため $70 \%$ の肝葉に虚血再灌流を負 荷し, 活性酸素による酸化ストレスの指標として肝組 織中 $\mathrm{PCOOH}$ 濃度を測定した. 本実験により, 現在ま で解析が困難であった細胞内 SOD 活性上昇の虚血再灌 流障害に与える影響の解析と, 細胞内で産生される活 性酸素の意義についての再評価が初めて可能となった。

\section{対象と方法}

\section{1. 対象}

Epstein らにより作成され, 東北大学医学部第 1 外科 で継代している transgenic mouse を, ICR マウス(エ スエルシー, 静岡) と交配し, 8 週齢の雄性の $\mathrm{F}_{1}$ (体重 
35〜 40g)を PCR 法にて選別した。すなわち，既知の human sodl gene の塩基配列よりプライマーを設計し, 尾静脈血中のDNAをPCR法にて増幅, h-sod 1遺伝 子を有するtransgenic群 ( $\mathrm{Tg}$ 群), 遺伝子を有しない control 群 (C 群)の選別を行い, 以下の実験に供した. なお, 今回用いた transgenic mouse は長期飼育を行っ ても正常マウスと比較し体重, 寿命に差はなく, 明ら かな疾病の発生等を認めなかった。

\section{2. 実験方法}

$\mathrm{Tg}$ 群, C 群の両群を, 虚血時間/再灌流時間により, 0分/0分群, 15 分/0分群, 15 分/15分群, 15 分 $/ 45$ 分群の 4 つの亜群に設定した(各亜群 $n=5) .1$ 昼夜絶食とし, pentobarbital $40 \mathrm{mg} / \mathrm{kg}$ の腹腔内投与で麻酔を施行 後, 腹部正中切開で開腹し, ヘパリン(ヘキスト薬品工 業, 東京) 400 単位 $/ \mathrm{kg}$ を尾静脈より投与後, HigginsAnderson ${ }^{12}$ の $70 \%$ 肝切除法と同様に肝の正中葉と左外 側葉の門脈, 肝動脈を一括して血管クリップ $(\mathrm{MEH}$ DORN-CLIP, AESCULAP 社, Germany)を用いて遮 断し，70\%の肝虚血を生じさせた。15分間の血流遮断 を行い, 再開腹後クリップを除去し, あらかじめ亜群 別に設定した時間の再灌流を行った。虚血開始前, 再 灌流直前, 再灌流15分後, 再灌流45分後に虚血再灌流 を行った肝葉を採取し,ただちに液体窒素にて凍結, 測定までー $80^{\circ} \mathrm{C} て ゙$ 保存した. 採血は下大静脈穿刺にて 行い, ただちに血獎を分離し凍結保存した. 血漿より alanine aminotransferase(ALT) とヒアルロン酸濃度 を測定した.また再灌流障害の指標として, $\mathrm{PCOOH}$ の 肝組織中濃度の測定を行った。

\section{3. 各種パラメーターの測定法}

i ) ALT はスポットケム(京都第一科学)を用い,ドラ イケミストリー法で測定した。

ii）血漿ヒアルロン酸濃度 Hyaluronic acid binding protein を用いた Sandwich binding protein assay 法 (ヒアルロン酸プレート「中外」)により定量した.

iii）肝組織中 $\mathrm{PCOOH}$ 濃度 $\mathrm{PCOOH}$ は宮沢ら ${ }^{13)}$ の方 法に準じて, high performance liquid chromatography-chemiluminescence 法(HPLC-CL 法)にて測 定した。脂質の抽出は以下のように行った。凍結保存 肝 $200 \mathrm{mg} に, 0.002 \%$ butylated hydroxytoluene (BHT) 含有生理的食塩水を加えてホモジネート作成し, クロロホルム/メタノール合剤 $(2: 1)$ を加え振盪擋汼し chloroform 層に脂質を溶解させ, $4^{\circ} \mathrm{C}, 3000 \mathrm{rpm}$ で10 分間遠心を行ったあと, 下層のクロロホルムを採取す る操作を 3 回反復した。採取した chloroform 層は evapolator $に て$ 蒸発濃縮し, chloroform $(400 \mu l)$ に再 溶解させ試料とした。

試料の $20 \mu l$ を HPLC(カラム: Finepak SIL NH2-5 日本分光, 東京) で分離しチトクローム C とルミノール を加え化学発光させ, 専用の検出器 (東北電子産業, 仙 台)で検出した. $\mathrm{PCOOH}$ 量は, 東北大学農学部機能分 子解析学教室より提供された $\mathrm{PCOOH}$ 標品との面積比 から算出した. 肝組織 $\mathrm{PCOOH}$ 濃度は, コリンオキシ ダーゼ・DAOS 法 (リン脂質 C一テストワコー, 和光純 薬工業)で測定した抽出脂質中のリン脂質量で補正した。 iv) SOD 活性 肝組織中の SOD 活性の測定は以下の ように行った. 脱血採取した肝組織を 30 倍の生理的食 塩水にてホモジネート作成し, 上清を $1000 \mathrm{~g}, 4^{\circ} \mathrm{C}, 10$ 分間遠心し, 上清をさらに $10000 \mathrm{~g}, 4{ }^{\circ} \mathrm{C}, 10$ 分間遠心 した。得られた上清を細胞質分画, 沈渣を超音波処理 し生理的食塩水に愻濁したものをミトコンドリア分画 とした。これらの分画中および血漿の SOD 活性の測定 は NBT 還元法 (SOD テストワコー, 和光純薬工業)に て行った。同試料に $5 \times 10^{-3} \mathrm{M}$ の $\mathrm{KCN}$ 溶液を加えた際 の SOD 活性を Mn-SOD 活性とし, 総 SOD 活性と Mn -SOD 活性の差を $\mathrm{CuZn-SOD}$ 活性とした. 肝組織分画 中の活性值については, Bradford 法で測定した試料中 の蛋白濃度で補正を行った.

\section{4. 統計的検討}

各測定值は. Two factor factorial ANOVA (StatView4.5)を用いて検定し, post hoc test として Fisher's PLSD を用いた. SOD 活性の検定には Student's t-test (StatView4.5)を用いた。結果は平均士標 準誤差(S.E.M.)で表示し, 有意水準は $\mathrm{p}<0.05$ とし た.

\section{成 績}

Fig.1に示す如く, Tg 群と C 群の総 SOD 活性は, ミトコンドリア分画と血獎では差がなかったが, 細胞

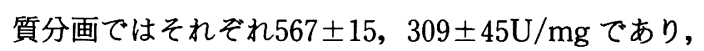
$\mathrm{Tg}$ 群は C 群の約1.8倍の総 SOD 活性を有していた。両 群の細胞質の CuZn-SOD 活性はそれぞれ508 15 , $268 \pm 33 \mathrm{U} / \mathrm{mg}$ であり, Tg 群の総 SOD 活性の上昇は $\mathrm{CuZn-SOD}$ 活性の上昇によるものであった.

$\mathrm{ALT}$ 值は, 再灌流15分後では C 群, $\mathrm{Tg}$ 群において それぞれ $91.2 \pm 17.8,18.8 \pm 7.8 \mathrm{IU} /$ lであり，C群は 虚血前值に比べ有意に上昇していたが, $\mathrm{Tg}$ 群において は ALT 值の上昇を認めなかった。再灌流45分後には, $\mathrm{Tg}$ 群においても $175 \pm 12.3 \mathrm{IU} / l$ と ALT の上昇が見ら れるが, C 群 $234 \pm 2.7 \mathrm{IU} / l$ と比較し有意にその上昇が 


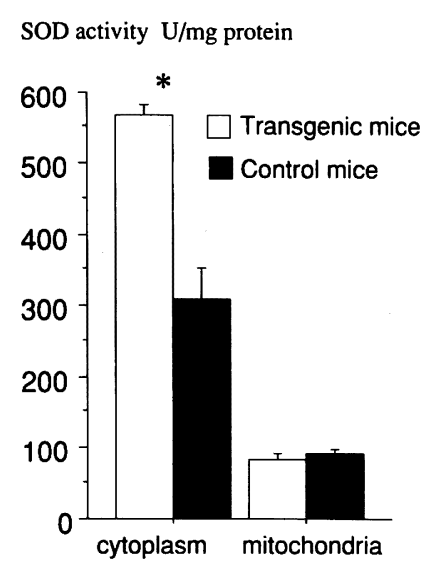

a

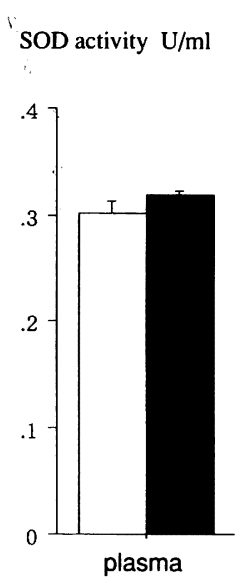

b

Fig. 1 Activity of superoxide dismutase in transgenic mice and control mice, a : activity in fractions of cytoplasm and mitochondria, $b$ : activity in plasma.

* $: p<0.001$ vs control mice (student's t-test).

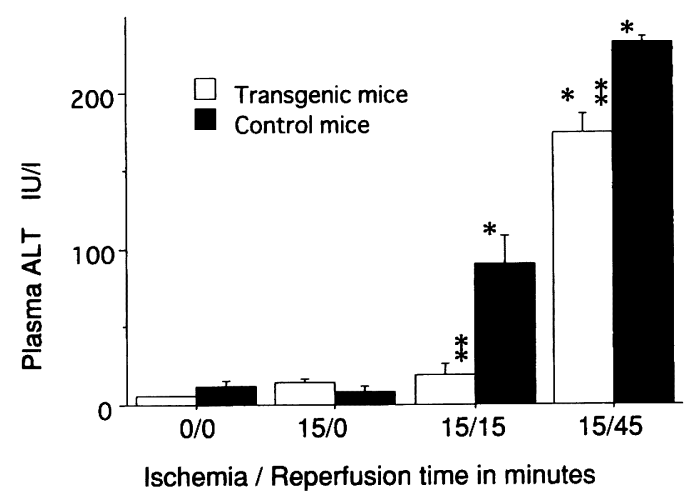

Fig. 2 Changes in plasma ALT undergoing ischemia/reperfusion. * $: p<0.05$ vs $0 / 0$ (Fisher's PLSD), ${ }^{* *}: \mathrm{p}<0.05$ vs control mice(Fisher's PLSD).

\section{抑えられた(Fig.2)。}

Fig.3に肝組織中 PCOOH の変化を示す.C群では再 灌流15分, 45分で1309 $\pm 115,1537 \pm 379 \mathrm{pmol} / \mathrm{mg}$ phospholipid (PL) と著明な上昇を認めた。対して Tg 群 では15分では $\mathrm{PCOOH}$ の上昇を認めず，45分で764士62 $\mathrm{pmol} / \mathrm{mgPL}$ と, C群に比較して有意に上昇が抑制され た.

血清ヒアルロン酸は $\mathrm{Tg}$ 群, C 群で虚血前がそれぞれ $273.3 \pm 45.9,259.4 \pm 40.2 \mathrm{ng} / \mathrm{m} l$ で, 再灌流45分後で

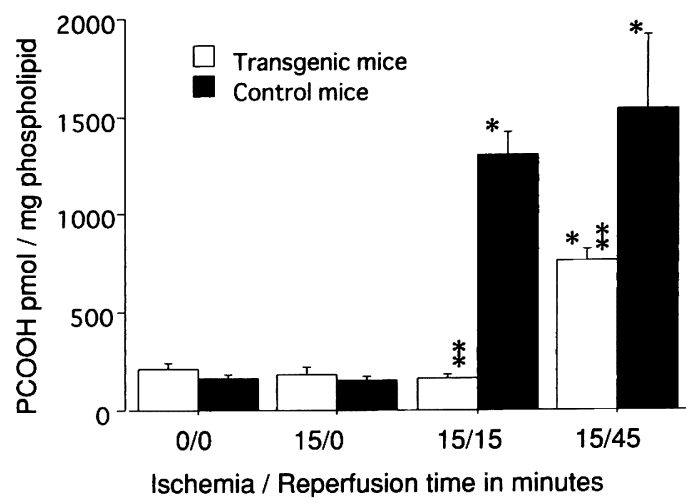

Fig. 3 Changes in $\mathrm{PCOOH}$ concentrations in liver tissue undergoing ischemia/reperfusion. ${ }^{*}: \mathrm{p}<$ 0.05 vs $0 / 0$ (Fisher's PLSD), ${ }^{* *}: \mathrm{p}<0.05$ vs control mice(Fisher's PLSD).

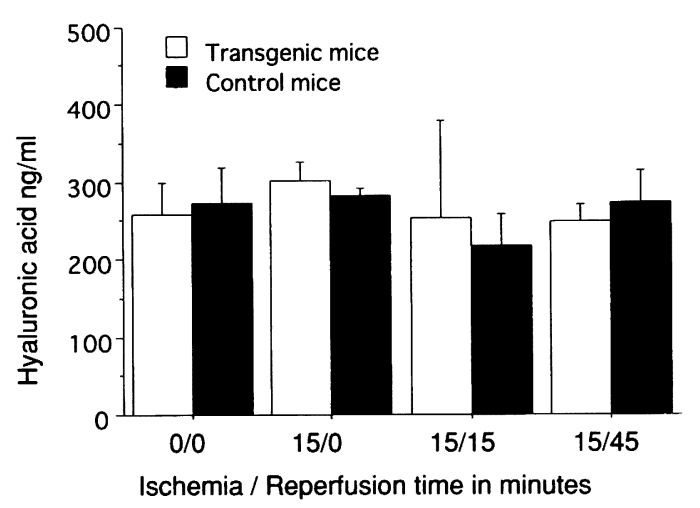

Fig. 4 Changes in hyaluronic acid concentrations in plasma undergoing ischemia/reperfusion.

それぞれ $272.4 \pm 41.8,248.0 \pm 22.8 \mathrm{ng} / \mathrm{m} l$ であり，虚 血および再灌流を通じて両群とも変化を認めなかった (Fig.4).

\section{考 察}

肝臓外科手術において, 肝実質切離時に流入血行路 遮断を施行する限り, 肝の虚血再灌流障害の発生は不 可避である。それゆえ再灌流障害の発生機序解明は, 肝障害の軽減および治療に直結した重要な課題といえ る.

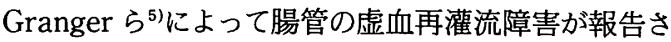
れ, 障害の mediator としての活性酸素の役割が注目さ れてきた.活性酸素の産生系について McCord ${ }^{14}$ ( は細胞 内の現象を重視し, 虚血時に酸素の供給が絶たれると ATPがヒポキサンチンにまで分解され蓄積し,また一 
方では虚血によって細胞内のキサンチン脱水素醅素 $(\mathrm{XDH})$ がキサンチン酸化酵素 $(\mathrm{XOD})$ に転換され, 再灌 流時に多量の酸素が供給されると，ヒポキサンチンが $\mathrm{XOD}$ によりキサンチンに分解される際に $\mathrm{O}_{2}^{-}$が発生す る説を提唱した。しかし, 現在, 多くの研究者は以下 に述べる諸事情から,これら XOD 系の $\mathrm{O}_{2}^{-}$産生機序へ の関与について種々の疑問をいだいている わち大量の $\mathrm{O}_{2}^{-}$を産生するだけの XOD が変換されるに は虚血時間が数時間を要するため実状にそぐわないこ と.また, 従来からアロプリノール投与により虚血再 灌流障害が軽減され, 本薬剤が XOD の阻害郕であるこ とが XOD 系による $\mathrm{O}_{2}^{-}$産生の傍証とされてきたが,ア ロプリノール自体に $\mathrm{O}_{2}^{-}$や hydroxyradical の消去作用 があることが判明し因果関係が混沌としてきたこと. さらに外因性 SOD 投与は肝虚血再灌流障害の軽減効 果を有するが, SOD 自体は細胞膜を通過しないため, 細胞内で生じるラジカル自体が再灌流障害の主役でな い可能性が指摘されてきたことなどである.しかし， これらの反証的事実があるものの肝における再灌流障 害において, 実際に細胞内の XOD が $\mathrm{O}_{2}^{-}$産生源として 働くのか, さらに生成する $\mathrm{O}_{2}^{-}$が細胞障害を起こしうる のか否かに関する論議には未だ決着が着いたとはいえ ない. そのため, 今回の実験は, 細胞内の $\mathrm{O}_{2}^{-}$を特異的 に消去しうる条件下で再灌流障害の生じる変化を検討 することを目的とし, 細胞質で SOD 活性の高い transgenic mouse を用いた. SOD は CuZn-SOD, Mn-SOD, Extracellular SOD (EC-SOD) の3つのアイソザイムが 存在し, CuZn-SOD は細胞質, Mn-SOD はミトコンド リア，EC-SOD は血漿中に局在することが知られてい る.ミトコンドリア中の $\mathrm{Mn}-\mathrm{SOD}$ 活性は酸化的ストレ スやサイトカインにより誘導を受けることが知られて いるが, 細胞質中の $\mathrm{CuZn-SOD}$ 活性は外来刺激による 発現の誘導は見られず，また体外からの投与によるSOD は細胞膜を通過しないため, 細胞質 SOD 活性を高めて 特異的に $\mathrm{O}_{2}^{-}$を消去する実験系の設定は不可能であった。 今回実験に用いた transgenic mouse は, ヒトの $\mathrm{CuZn}$ -SOD 遺伝子である h-sod 1 gene を発現し, 血漿, ミ トコンドリア分画においては $\mathrm{Tg}$ 群と C 群において差 がなく, 細胞質分画で $\mathrm{Tg}$ 群は約1.8倍の総 $\mathrm{SOD}$ 活性 を示した.この総 SOD 活性の増加は, CuZn-SOD 活性 の増加によることが確認された。このモデルにおいて は, 血槳中およびミトコンドリアの SOD 活性には差が ないことから, 好中球の NADPH oxidase 系に由来す る $\mathrm{O}_{2}^{-}$産生や, ミトコンドリア内で生じるとされる再灌
流時の電子伝達系の乱れによる $\mathrm{O}_{2}^{-}$産生の影響は除外で きる.すなわち今回の SOD マウスを用いた肝の虚血再 灌流実験の検討に扔いて, 血漿 ALT と肝組織中の $\mathrm{PCOOH}$ の増加が $\mathrm{Tg}$ 群で抑制されたことは, 細胞質内 で実際に $\mathrm{O}_{2}^{-}$が産生され再灌流障害の原因となっている ことを実験的に証明したものとして重要な意義を有す る.しかし再灌流障害が完全に抑制されなかったこと には 2 つの原因が考えられる.1つは細胞内 SOD 活性 が1.8倍に上昇していても消去しきれない活性酸素の産 生があったこと.もう 1 つは NADPH oxidase など細 胞外からの $\mathrm{O}_{2}^{-}$もる程度の細胞膜脂質の過酸化を生じ させていることである.

また再灌流障害の指標の 1 つとして, 今回の検討で 膜脂質過酸化物の $\mathrm{PCOOH}$ を選択した理由は, 以下に 述べるとおりである. 不飽和脂肪酸は最も酸化を受け やすい生体分子であり, 細胞膜の構成リン脂質の大部 分を占める phosphatidylcholine の過酸化物である $\mathrm{PCOOH}$ は, 再灌流により活性酸素が産生されると組 織中に増加する. 過酸化脂質の定量法として従来汎用 されたTBA 反応を利用する方法では, 種々のクラスの 脂質の過酸化物およびその代謝産物の総和を測定する ことになり, 測定する実体が不明瞭で, 特異的に 1 種 類の膜脂質過酸化を測定することは不可能であった. 宮沢らの考案した HPLC-CL 法は PCOOH のみを高感 度に定量する方法で, われわれは HPLC-CL 法で測定 した組織中および血獎中 $\mathrm{PCOOH}$ が鋭敏に肝虚血再灌 流障害を反映する指標となることを明らかにしている ${ }^{18)}$. 血中のヒアルロン酸は, そのほとんどが肝類洞内皮 細胞に取り込まれ, すみやかに分解されるため, 血中 ヒアルロン酸濃度は肝類洞内皮細胞機能を反映すると 考えられている ${ }^{19}$. 肝類洞内皮細胞は虚血再灌流障害で 比較的すみやかに傷害される部位であり, 低温保存肝 の移植に際しても, ヒアルロン酸のクリアランスは保 存時間に依存して悪化することが知られている ${ }^{20)}$. また 血中ヒアルロン酸濃度は肝の虚血開始時よりすみやか に上昇し, 再灌流直後でピークを形成し以後漸減する 動態を示すことが報告されているが21), われわれの実験 系では両群とも虚血による上昇を認めなかった。 今回 のモデルは $70 \%$ の肝虚血であったため，30\%の肝に血 流が温存されればヒアルロン酸のクリアランスとして は充分となり，血中濃度は虚血による上昇をきたさな かったことが理由と考えられた。また，ヒアルロン酸 濃度はたしかに再灌流障害を反映するが, 実際の生体 膜の脂質過酸化反応を直接に反映しない.今回，血槳 
ヒアルロン酸值が C 群においても再灌流後の上昇を認 めなかったが，この現象には肝類洞内皮細胞傷害が, 今回の15分という比較的短時間の虚血では生じなかっ たことに原因がある.しかしそのような短時間虚血で も細胞内では再灌流により活性酸素が産生され, 脂質 過酸化という再灌流障害の初期のステップが始まって いることが, 膜脂質過酸化反応を鋭敏に検出する肝組 織中 $\mathrm{PCOOH}$ 濃度の上昇から明らかになった。この事 実は, 類洞内皮細胞を直接傷害する好中球 $\mathrm{NADPH}$ oxidase 系由来の $\mathrm{O}_{2}^{-}$が, 肝の虚血再灌流障害発症の主 役とする従来の考え方に疑問を投げかけるものである が, 細胞内 $\mathrm{O}_{2}^{-}$消去能の向上が有効な再灌流障害の軽減 法の 1 つとなりうることを示唆する重要な所見である. また, 細胞質内 $\mathrm{CuZn}-\mathrm{SOD}$ 活性の上昇は肝の非実質細 胞にも同様に誘導される. 肝虚血時間を本実験の15分 より延長した場合, 細胞内 superoxide 消去能の向上が 予想される類洞内皮細胞傷害の軽減に寄与することが 予想される。

本来, 他蔵器と異なり肝蔵にはグルタチオンや $\alpha-ト$ コフェロール, coenzyme $\mathrm{Q}$ など非特異的抗酸化物質 が豊富に存在し, 酸化ストレスには比較的抵抗性と考 えられてきた。今回の結果からは，これらの抗酸化物 質は再灌流開始後すみやかに消費されるため, 細胞質 SOD 活性の賦活が再灌流障害を軽減したと考えられる. 近年の遺伝子導入技術の進歩により一過性の肝細胞へ の遺伝子の導入が可能となりつつある. SOD の細胞内 への導入が近い将来技術的に可能となれば，虚血再灌 流障害の緩和に対する臨床応用も期待される，最近ア デノウイルスベクターを用いて Mn-SOD をマウス肝に 導入することで, 虚血再灌流障害の軽減と炎症性サイ トカインの発現を促進する NF- $\beta$ の活性化が抑制さ れることが示された ${ }^{22)}$. Mn-SOD はミトコンドリアに 局在するため, 過剰発現の効果は再灌流後のエネルギー 代謝の改善に寄与する可能性を有するが, CuZn-SOD の活性上昇は細胞質全般に見られるもので, 生体膜過 酸化反応の抑制効果が期待される. CuZn-SOD, Mn -SOD を別個に過剰発現させることは異なった意義を有 する.術前から効果的に細胞内の SOD 活性を高める具 体的な方法の開発は, 肝虚血再灌流障害の緩和策とし て，臨床に直結した重要な検討事項と考えられる。

\section{結論}

1） $70 \%$ 肝虚血15分，再灌流45分の負荷により，マウ ス肝に膜脂質過酸化・肝機能障害が惹起された。

2）細胞質の SOD 活性が約1.8倍に上昇した trans- genic mouse で, 肝虚血再灌流障害が軽減された。

3） 15分の部分肝虚血では, 肝類洞内皮細胞機能の障 害を認めなかった。

4）肝の虚血再灌流障害では細胞質においても $\mathrm{O}_{2}^{-}$産生 が起こっており, 細胞質の活性酸素消去能の向上は再 灌流障害の予防に効果的と考えられた。

稿を終えるにあたり,研究の全般にわたりお手伝い頂いた 教室の渋谷恵美子女史に, 樑く感謝いたします。

なお, 本稿の要旨は第33回日本肝臓学会総会において発表 した.

\section{文献}

1) Nauta RJ, Tsimoyaiannis E, Uribe M, et al : Oxygen-derived free radicals in hepatic ischemia and reperfusion injury in the rat. Surg Gynecol obstet 171:120-125, 1990

2) Bovaris A, Cadenas E, and Stoppani AOM : Role of ubiquinone in the mitochondrial generation of hydrogen peroxide. Biochem J 156 : 435-444, 1976

3) Htwe T, Suzuki M, Ouchi K, et al : Effects of urinastatin and free radical scavengers on hepatic lipid peroxidation in endotoxemia. J Surg Res 61:206-214, 1996

4）武藤大成, 鈴木正徳, 福原賢治, 他：初代培養肝 細胞のエンドトキシンに対する膜脂質過酸化反応 一特に Kupffer 細胞の関与について一. 肝臓 $35: 601-608,1994$

5) Granger DN, Rutili G, McCord JM : Superoxide radicals in feline intestinal ischemia. Gastroenterol $81: 22-29,1981$

6) Jaeschke $H$ : Neutrophils contribute to ischemia/reperfusion injury in rat liver in vivo. FASEB J. $4: 3355-3359,1990$

7) Tamura M, Nakajima $Y$, Omura $K$, et al : Can anti-Mac-1 and anti-TNF monoclonal antibody protect the liver from warm ischemiareperfusion injury in mice? Transplant Proc $27: 768-770,1995$

8) Nakano H, Kuzume M, Namatame K, et al : Efficacy of intraportal injection of anti-ICAM1 monoclonal antibody against liver cell injury following warm ischemia in the rat. Am J Surg $170: 64-66,1995$

9) Vollmar B, Glasz J, Menger MD, et al : Leukocytes contribute to hepatic ischemia/re- 
perfusion injury via intracellular adhesion molecule-1-mediated venular adherence. Surgery $117:$ 195-200, 1995

10) Oshiro $Y$, Marubayashi $T$, Maeda $T$, et al : Contribution of neutrophils on ischemia and reperfusion injury in rat livers. Transplant Proc 27:743-744, 1995

11) Epstein CJ, Avraham KB, Lovett M, et al : Transgenic mice with increased $\mathrm{Cu} / \mathrm{Zn}$ superoxide dismutase activity: Animal model of dosage effects in Down syndrome. Proc Natl Acad Sci USA 84:8044-8048, 1987

12) Higgins GM and Anderson RM : Experimental pathology of the liver. Arch Pathol 12: 186-202, 1931

13) Miyazawa $T$, Yasuda $K$, Fujimoto $K$ : Chemiluminescence-high performance liquid chromatography of phosphatidylcholine hydroperoxide. Anal Lett $20: 915-925,1987$

14) McCord JM : Oxygen-derived free radical in postischemic tissue injury. N Engl J Med 312 : 159-163, 1985

15) Betz AL, Randall J, Martz D : Xanthine oxidase is not a major source of free radicals in focal cerebral ischemia. Am J Physiol 260: H563-H568, 1991

16) Marubayashi S, Dohi K, Yamada K, et al : Role of conversion of xanthine dehydrogenase to oxidase in ischemic rat liver cell injury.
Surgery $110: 537-543,1991$

17) Das DK, Engelman RM, Clement R, et al: Role of xanthine oxidase inhibitor as free radical scavenger : a novel mechanism of action of allopurinol and oxypurinol in myocardial salvage. Biochem Biophys Res Commun 148: $314-319,1986$

18）福原賢治, 鈴木正徳, 海野倫明, 他：細胞膜脂質 過酸化物 phosphatidylcholine hydroperoxide 血 中濃度による肝虚血再灌流障害の評価. 日外会誌 $98: 470,1997$

19) Ichida $K$, Sugitani $S$, Satoh $T$, et al : Localization of hyaluronan in human liver sinusoids: a histochemical study using hyaluronan-binding protein. Liver 16 : 365-371, 1996

20) Itasaka H, Suehiro T, Wakiyama $S$, et al : Significance of hyaluronic acid for evaluation of hepatic endothelial cell damage after cold preservation/reperfusion. J Surg Res 59 : $589-595,1995$

21）野口 孝, 北川真人, 櫻井洋至, 他：虚血肝障害 における類洞壁細胞機能の可逆性とその評価一実 験的·臨床的検討一. 外科 $57: 1213-1216,1995$

22) Zwacka RM, Zhou W, Zhang Y, et al : Redox gene therapy for ischemia/reperfusion injury of the liver reduces $\mathrm{AP} 1$ and $\mathrm{NF}-\boldsymbol{x} \boldsymbol{\beta}$ activation. Nature Med 4:698-704, 1998 


\title{
Increased Activity of Superoxide Dismutase in Cytoplasm Attenuates Ischemia/Reperfusion Injury of Murine Liver
}

\author{
Heigo Takeuchi, Masanori Suzuki, Kenji Fukuhara, Michiaki Unno, \\ Takayuki YAMAKI and Seiki Matsuno
}

Reactive oxygen species have been involved in pathogenesis of ischemia/reperfusion injury of the liver. It is hypothesized that the phagocytic cells mainly generate the free radicals in reperfusion injury. The aim of this study was to determine whether superoxide radicals are generated in cytoplasm following warm ischemia/reperfusion of murine liver. Transgenic mice overexpressing $\mathrm{Cu} Z n$ superoxide dismutase and normal mice underwent partial-liver ischemia and reperfusion for this purpose. Partial ischemia was performed by clamping hepatic vessels of left and median lobes for 15 minutes. We measured alanine aminotransferase (ALT), hyaluronic acid and phosphatidylcholine hydroperoxide (PCOOH) which was a primary peroxidative product of main component of cell membrane. Forty-five minutes after reperfusion, plasma ALT and $\mathrm{PCOOH}$ concentration in the liver were significantly decreased in transgenic mice compared to normal mice. These results suggest that superoxide radicals produced in cytoplasm play a definitive role in the tissue injury after reperfusion of the liver.,

First Department of Surgery, Tohoku University School of Medicine 